Article

\title{
The Rights Network: 100 Years of the Hohfeldian Rights Analytic
}

\author{
Jack Clayton Thompson \\ Lecturer in Law, University of Westminster, London W1W 7UW, UK; thompsj@westminster.ac.uk
}

Received: 4 May 2018; Accepted: 11 July 2018; Published: 16 July 2018

\begin{abstract}
This paper sets out to reconsider the Hohfeldian framework of rights in celebration of the centenary anniversary of their original publication. It begins by conceptualizing each of the Hohfeldian incidents or rights before outlining the molecular or complex structure of rights to "things". I adopt a broad use of the term of "right" and apply it to Legal, Moral, Equitable and Human conceptions and constructions. It sets out an argument in favor of a further definitional model-in addition to Hohfeld's scheme of opposites and correlatives-which focuses on the function of these conceptual rights. Finally, it sets out to provide a model of rights as forming a network within a given community and the exponential growth of "rights-connections" within an expanding community. This is used to frame responses to common criticisms of "rights talk" and the balance of benefits and burdens on account of such a rights network. Ultimately, this paper seeks to demonstrate the benefit, and indeed necessity, of the Hohfeldian model in any discussion of rights. Without it "rights talk" is debased and impoverished.
\end{abstract}

Keywords: rights; duties; Hohfeld; obligations; network; human rights

\section{Introduction}

It is 100 years since Wesley Hohfeld's untimely death (Brady 1972). Hohfeld's essays entitled, "Fundamental Legal Conceptions as Applied in Judicial Reasoning" set out to explain and define the different ways in which jurists and lawyers use the term "right". ${ }^{1}$ In doing so, it provided modern rights-theorists with a concise, elegant, and analytic structure for the understanding of rights and how these jural relations affect the benefits and burdens between persons, both conceptually and normatively. Unfortunately for us, the follow up to these essays was not forthcoming (Hohfeld 1964) ${ }^{2}$, and with it, a wealth of further material was lost. Instead, it has remained the pastime of others to take forward those foundations. With it a range of new ideas around the Hohfeldian schema have been put forward. Yet Hohfeld's own formulation remains the most widely adopted. Its impact is felt throughout the majority of literature that contains any reference to rights (or it ought to). Subtle mentions of claim-rights are a welcome addition for the Hohfeldian. They are placed like inside jokes within far grander examinations of law, morality, and politics. ${ }^{3}$

1 (Hohfeld 1917a) 26 Yale Law Journal 710. Part I: (Hohfeld 1913a) 23 Yale Law Journal 16. Published together in (Fundamental Legal Conceptions as Applied in Judicial Reasoning) (Hohfeld 1964).

2 Indeed the scope of his intended analysis can be gleaned early in Fundamental Legal Conceptions 1917 (Fundamental Legal Conceptions as Applied in Judicial Reasoning) (Hohfeld 1964), pp. 69-70) where he noted 'Some of such overspreading classifications consist of the following: relations in personam ("paucital" relations), an relations in rem ("multital" relations); common (or general) relations and special (or particular) relations; consensual and constructive relations; primary and secondary relations; substantive and abjective relations; perfect relations and imperfect relations; concurrent (i.e., relations concurrently legal and equitable) and exclusive relations (i.e., relations exclusively equitable) ... the following pages will be confined to the first classification above indicated, viz., relations in personam and relations in rem.'

3 Perhaps by grander I mean the emotive issues to which we seek to assert our rights, see Corbin, xiv; such excitement or emotion is rarely aroused by the demonstration of the conceptual differences between an assertion of a right and a privilege. 
For Hohfeld, his concern was to assess the meaning of assertions to rights ("I have a right to X" or "I have a right that you X"), predominantly regarding proprietary and equitable rights. Though not limited to this domain alone, reading both essays and his other works, it is ostensible where Hohfeld's interest and intellectual pursuit lay (Hohfeld 1917b; Hohfeld 1913b). Over the past 100 years, the terminology of rights has changed immensely. Scholars are concerned with Legal, Equitable, Moral and Human rights. In this paper, I adopt a broad use of the term "right". It is used interchangeably for Legal, Equitable, Moral and Human rights. I do so on the basis that I am not concerned, for present purposes, with the source or justification for the right's existence but with the conceptual meaning of "right" as a tool used in legal and moral discourse.

The introduction of the European Convention on Human Rights, and in the UK, the Human Rights Act 1998 (and possible withdrawal and replacement with a "Bill of Rights"), has created a discourse within and response to rights-talk as something overtly concerned with an individual right-holder and their ability to exert control and power over another person or the State, or their freedom from the power of the State. It is in accepting a set of rights that we approve of a distribution of freedom and authority within society, and therein aim to achieve equality between members of that society and rules governing reasons for inequality. ${ }^{4}$ As Campbell notes,

'Rights currently enjoy a highly favourable reputation. The discourse of rights is pervasive and popular in politics, law and morality. There is scarcely any position, opinion, claim, criticism or aspiration relating to social and political life that is not asserted and affirmed using the term 'rights'. Indeed, there is little chance that any cause will be taken seriously in the contemporary world that cannot be expressed as a demand for the recognition or enforcement of rights of one sort or another. It is not enough to hold that a proposal will lead to an improvement in wellbeing or reduction in suffering, unless it can also be presented as a recognition of someone's rights, preferably their human rights. We live in 'The Age of Rights'.' (Campbell 2006, p. 3).

For many, it is tempting to frame most assertions to justice in the language of rights (Griffin 2008, pp. 14-15; Glendon 1991). However, this proliferation of rights talk comes at the expense of the analytical basis (Cornell 2015). Elsewhere, rights continue to hold precedence and indeed are used to form complex liberal democracies aiming to recognize contextual and relational issues through mutualist rights (Gewirth 1996).

The world since Hohfeld has contracted. Globalisation has led to a merging of states and statehood. ${ }^{5}$ Supra-national legislation is commonplace, and with it, supra-national rights. Moral, Legal and Human Rights are juxtaposed and run through modern rights discourse, often without distinction. Rights are positive and negative, universal and specific, in personam and in rem, absolute and qualified. Yet Hohfeld's schema remains an accomplished device for the analysis of all this (Stone 1964, p. 161). As Corbin noted in the introduction to Fundamental Legal Conceptions,

'Such an understanding merely helps to clarify the issue, and to know that when one is fighting for a "right", he is asking the state (the public organization of men) to create and enforce a "duty" on another, and that when he is fighting for a "privilege" he is asking the state to deprive another of an existing "right".' (Corbin in Hohfeld 1964, p. xi)

Indeed, many of these questions were dealt with by Hohfeld himself in the two Fundamental Legal Conceptions essays before it was cut short by his death.

In this paper, I set out to return to Hohfeld's own work and consider how the work of subsequent scholars has added to his own formulations. This paper does not set out to consider what rights

4 By this, I mean the rules that justify giving rights to persons outside of that which is generally applicable to create equality-for instance, rules which allow judges, police officers, etc., the right to do that which the general public cannot.

5 Albeit that this appears to be retreating at present. 
a person has, nor what rights they ought to have. Rather, it focuses on understanding our use of the term "right" to provide it with a conceptual and functional underpinning. This is not simply a restatement of the Hohfeldian framework. Instead, I offer delineation of the Hohfeldian schema and development of those ideas as a modern applicatory framework of the rights analytic. I propose an analytical tool based on Hohfeld's framework as a network existing across a community for testing any rights-based assertion or, more broadly, any rights-based system or society. I use the conception of the rights network to explain the importance of rights exemplification within communities as related to Hohfeldian multital rights, whilst also responding to some of the most common challenges to rights generally, as well as the Hohfeldian conception of rights.

In order to reach this aim, this paper will work through the following structure: first, I set out Hohfeld's original schema of assertions to rights and correlative obligations; second, I will consider how these individual rights can form together to create complex, "molecular" rights to certain things; third, I will consider how these incidents function in relation to the right-holder(s) and obligation-bearer(s); fourth, I will consider the scope of these incidents against potential obligation-bearer(s); and finally, I will seek to demonstrate how these rights-based relations operate across a given society in order to form a rights network.

\section{Hohfeldian Rights and Obligations}

It is at this point that it is necessary to turn to the "Hohfeldian incidents". The primary purpose of which is, as noted, the elucidation of what is meant by an assertion of a right. These four basic incidents or rights—claim-right, privilege-right, power-right, and immunity-right, examined below-are all referred to as "rights" but should, due to their distinct individual and logical forms, be separated and narrowly defined. It is the ordered arrangement of these individual incidents that may form a complex internal structure of the more familiar rights—such as the right to bodily integrity or the right to private property - and combine to form what has been termed a molecular or complex right. Hohfeld's analysis tells us nothing of social policy nor of justice; it does, however, provide a tool for the analysis of legal problems and of the distribution of rights-duties. This, in turn, enables the analysis of those policies.

Despite the current popularity of rights-based theories, the distinction between (a) what a right is, and (b) what rights people actually (should) have, remains at the fore (Wacks 2009, p. 298). Overuse has led to the term "right" to become without criterion, and the language surrounding assertions to rights debased (Griffin 2008, pp. 14-15). This is undoubtedly a result of the utility of "rights-talk", however, this utility leads it to be degraded by wanton excess-asserting a right to $\phi$ or preclusion of $\phi$ a violation of a right does not make it so (White 1985, p. 130). The amplitude and ambiguity drain it of any real meaning and undermines the protection it seeks to secure. This was the very problem recognized by Hohfeld,

'One of the greatest hindrances to the clear understanding, the incisive statement, and the true solution of legal problems frequently arises from the express or tacit assumption that all legal relations may be reduced to "rights" and "duties", and that these latter categories are therefore adequate for the purpose of analyzing even the most complex legal interests, such as trusts, options, escrows, "future" interests, corporate interests, etc. Even if the difficulty related merely to inadequacy and ambiguity of terminology, its seriousness would nevertheless be worthy of definite recognition and persistent effort toward improvement; for in any closely reasoned problem, whether legal or non-legal, chameleon-hued words are a peril both to clear thought and to lucid expression' (Hohfeld 1964, p. 35).

It is for this reason that the starting point for understanding "rights" is a developed version of Hohfeld's attempt to clarify the proposition "X has a 'right' to do $\phi^{\prime}$, which led to the categorization of four distinct incidents (Wacks 2009, p. 280; Hohfeld 1964, pp. 5-6). 
The following outlines give a brief insight into what is essentially meant by each of these incidents: ${ }^{6}$

- "Y is under a duty to do $\phi$ in relation to $X$; thus, $X$ has a claim as against $Y$ ": this is a Claim-right.

- " $X$ is free to do or not do something; $Y$ owes no duty to $X$ nor $X$ to $Y^{\prime \prime}$ : this is a Privilege-right.

- "X has a power (or freedom) to do $\phi ; X$ is free to do an act that alters the legal position of $Y^{\prime \prime}$ : this is a Power-right.

- "X is not subject to Y's power to change another's legal position": this is an Immunity-right.

For each of these incidents there exists both an opposite and a correlative (Table 1):

Table 1. Scheme of Jural Relations (Adapted from Hohfeld 1964, p. 36, 65).

\begin{tabular}{ccccc}
\hline Hohfeldian Incident & Claim & Privilege & Power & Immunity \\
Jural Opposite & No-Claim & Duty & Disability & Liability \\
Jural Correlative & Duty & No-Claim & Liability & Disability \\
\hline
\end{tabular}

The term "Jural Relations" is used to denote a relationship between persons that are governed by rights and obligations (Corbin 1921, p. 227). I now focus on each of the Hohfeldian incidents to elucidate what is meant by each of the Jural Relations governing the interpersonal interactions of individuals. I will then go on to consider how each of these individual relations might come together to form complex, "molecular" rights.

\subsection{Claim-Rights and Duties}

" $\mathrm{X}$ has a claim that $\mathrm{Y} \phi$ if, and only if, $\mathrm{Y}$ has a duty to $\mathrm{X}$ to $\phi$

It is this first incident that is perhaps most closely associated with the "traditional" idea of a "right", hence why it is sometimes termed as a right "stricto sensu" (Veerman 1992, p. 14). For this reason, despite the "looseness of usage" (Hohfeld 1964, 36), Hohfeld terms this incident as "Right" with the correlative being a duty held by another. Hohfeld also recognised that it may be desirable to adopt a synonym in this regard; he found that the word "claim" would be the aptest (Hohfeld 1964, p. 38). For this reason, the term "Claim-Right" is adopted for the purpose of this paper.

For Hohfeld, it is appropriate to term this incident as a "right" because the correlative is a duty and the commonality of the understanding of the "right-duty" relationship justifies defining it so (Hohfeld 1964, p. 38). The relationship is essentially "A duty ... is that which one ought or ought not to do. 'Duty' and 'right' are correlative terms. When a right is invaded, a duty is violated. ${ }^{7}$ It was this clue found in the ordinary legal discourse that justified limiting the term "right" to mean this and only this incident.

\subsection{Privilege-Rights and "No-Claims"}

"X has a privilege to $\phi$ if and only if $\mathrm{X}$ has no duty not to $\phi . "$

As seen in the above Scheme of Jural Relations, a privilege is the opposite of a duty and the correlative of a "No-Claim". The expression of this incident is reliant upon the jural opposite, unlike a claim, which relies upon the jural correlative (Hohfeld 1964, p. 39). In this way, a privilege exists in the absence of a corresponding claim rather than on the requirement that another (not) act in some specified way, as indicated in Table 1. A privilege exists where the privilege-holder is neither

6 These are not intended to be definitions of the terms. Rather they set out the scope of the concept to allow the reader to understand Hohfeld's use of correlative and opposite in his concept formation.

7 Lake Shore \& MSR Co v Kurtz 1894, p. 304. 
compelled nor restrained from acting in a certain way; he is free to carry out his wishes without the interference of another. Hohfeld notes, "More than this, the dominant specific connotation of the term as used in popular speech seems to be mere negation of duty. This is manifest in the terse and oft-repeated expression, "That is your privilege,"-meaning, of course, "You are under no duty to do otherwise."' (Hohfeld 1964, p. 45) ${ }^{8}$ An example of this can be found in the following extract: " ... giving women any new privilege with the view of becoming solicitors or attorneys." ${ }^{\prime \prime}$ Therefore, if $X$ is a landowner with a claim that $Y$ will stay off his land, $X$ will have a privilege of entering onto the land. In other words, $X$ has no duty to stay off the land. As Hohfeld noted, "The privilege of entering is the negation of a duty to stay off" (Hohfeld 1964, p. 45). This is referring solely to a duty that has the content precisely opposite to the privilege that is concerned (Hohfeld 1964, pp. 38-39). It is, therefore, entirely possible for $X$ to have both a privilege to do $\phi$ and a duty to do $\phi$. For example, if $X$, in the above scenario, were to contract with $Y$ that the latter will enter the land, $Y$ would then have both a privilege of entering the land and a duty to do so as well. This is consistent with the above definition because the privilege and the duty have the same content; it is true that $\mathrm{X}$ has a privilege to do $\phi$ but it is not true that $X$ has a duty not to do $\phi$. Essentially, a privilege indicates those things that the bearer is not under a duty to refrain from performing, or not under a duty to perform (Hohfeld 1964, p. 45). It is hardly surprising, therefore, that this incident has sometimes been referred to as a "liberty" (Hohfeld 1964, pp. 48-49). A bearer's privileges are those actions that the bearer is free to choose to do, or free to do that others are generally not, such as to decorate one's property, to sit in an empty seat on a train, to buy groceries, or to walk along the street. An individual may gain the privilege to perform or engage in licensed activities with possession of a license; for example, the ability to drive with a full driver's license or to consume alcohol or cigarettes with valid identification.

\subsection{Power-Rights and Liabilities}

"X has a power to $\phi$ if and only if $\mathrm{X}$ is able to alter his own, or another's, 'rights'."

As seen in the scheme of jural relations, a power-right is the correlative of a liability and the opposite of a disability, as seen in Table 1. Similarly, we are able to reflect on our developed scheme, which shows us that a power-right is the second tier, active incident; meaning, it is a right that acts over other rights and requires the right-bearer to exercise the right. In order to properly understand what a power is, it is necessary to provide an accurate definition of what is meant by the correlative and the opposite given the use of these terms in common parlance.

A power-right, therefore, enables the bearer, in some way, to alter their own or other's incidents (Hohfeld 1964, pp. 50-51). Working from this point we are better able to provide a definition for the jural opposite and correlative. If the essence of a power is the ability to alter some legal position, then the jural opposite, a disability, indicates the inability to alter some incident (Wenar 2005). Likewise, the jural correlative, a liability, indicates that the person is liable to have his legal position altered by another bearing a corresponding power (Hohfeld 1964, p. 57).

\subsection{Immunity-Rights and Disabilities}

" $X$ has an immunity from $\phi$ if and only if $Y$ lacks the ability to alter $X$ 's 'rights'

8 Compare and contrast this with the rather curiously and confusingly worded expression of Lord Atkinson in Adam v. Ward [1917] AC 309, at 334: 'a privileged occasion is ... an occasion where the person who makes a communication has an interest or a duty, legal, social or moral, to make it to the person to whom it is made and the person to whom it is so made has a corresponding interest or duty to receive it. This reciprocity is essential.'

9 Bebb v Law Society 1914, p. 286, my emphasis. Here, the question was whether women held the right to become solicitors; that is, whether women were at liberty, in law, to enter the profession. A privilege-right must be constituted in the absence of a claim in another that one not become a solicitor. To frame such a right as a claim-right would entail that another was duty bound to allow the right-holder to become a solicitor. This simply cannot be what is meant. 
The final Hohfeldian incident is the immunity. An immunity-right is essentially the inability of others to alter the normative situation of the immunity-holder. So, if A lacks the power to alter the structure of B's Hohfeldian incidents then B has an immunity against A. The opposite of an immunity is a liability (to have one's normative situation altered), and the correlative is a disability (from changing the normative situation of the immunity-bearer), as outlined in Table 1 . The bearer of an immunity is protected from others by prohibiting the alteration of his normative situation, based on the absence of power (disability) in some other party (Hohfeld 1964, p. 60). This is the essential function of an immunity; it protects the bearer from harm or paternalism (Wenar 2005, p. 232).

\section{Molecular "Rights"}

Each of these Hohfeldian incidents can be described as "rights" in isolation, and commonly are described as such; it is also possible for the individual incidents to bond together to create complex rights (Hohfeld 1964, p. 96; Campbell 2006, p. 33). In this way, they are sometimes referred to as Molecular Rights comprised of numerous "atomic" incidents (Wenar 2011). The "rights" to things more often asserted (to property, body, etc.) will generally be of this complex, molecular type (Wellman 1975, p. 52).

Having considered the complex right in abstraction, it is now necessary to consider an applied and commonly held complex right. For this purpose, it will consider the right over one's body (or the right to bodily integrity). Having done so, it will then go on to look at the qualification of these various individual incidents. In the first tier, $\mathrm{X}$ has a claim against others touching his body-that is $\mathrm{A}, \mathrm{B}, \mathrm{C}$, $\mathrm{D}$, etc., owe $\mathrm{X}$ a duty not to touch his body. Equally, $\mathrm{X}$ has a privilege over moving, or not moving, his body as he so pleases. In the second tier are X's rights over his (or another's) other incidents. First is X's power to (not) authorize others to touch his body. By the same token, $X$ might transfer onto another the power to authorize others to touch his body. This incident gives the bearer discretion over whether to waive his claim against obligation-holders with respect to touching his body. Second is X's immunity from others waiving his claim against others touching his body (or, equally, against others creating a duty not to move his body—that is nullifying his privilege) (Campbell 2006, pp. 33-34).

The importance of the "molecularization" of rights ought not to be understated. It is in doing so that we can understand how familiar assertions to rights, such as the right to freedom of expression or the right to bodily integrity, may be transposed into the Hohfeldian schema (Hohfeld 1964, p. 96; Halpin 2007, p. 31). Equally, it allows us to confirm that the incidents themselves, for the most part, are not stand-alone rights, but exist within a complex structure at multiple levels. For instance, the combination of Claim-Rights with Power-Rights is a useful device for conceptualizing the role of consent in the Rights Analytic. Similarly, we might explain how infringing an individual's Privilege-Right to $\phi$ might create a secondary Claim-Right to rectify the harm incurred (Halpin 2007). Most importantly, at this stage we are afforded a means of deconstructing any assertion to a right. It will either:

1. Assert the right holder's ability to (not) perform some act- "X has a right to (not) $\phi$ ",

2. Assert the duty bearer's requirement to (not) perform some act- "X has a right that $Y$ (not) $\phi^{\prime \prime}$; or,

3. It is an assertion that one has a right in or to a thing- "X has a right to $A$ ".

If the assertion falls into category 1 , it will be an assertion to either a Privilege-Right or a Power-Right. If it falls into category 2, it is either a Claim-Right or an Immunity-Right. If it falls into category 3 , then it may be a complex right which requires deconstruction as to its constitutive elements, without which the assertion is meaningless because it will fail to denote either the correlative duty-bearer or the permitted or prohibited action (Halpin 2007, p. 32).

This is the strength of the Hohfeldian method; amid accusations that rights talk is debased and meaningless, that the rights-based approach is overly individualized and focused purely on the rights-holder, it is in the thoroughness of the analytic that we are enabled to thoughtfully consider the merits and the meaning behind assertions to rights. Much as rules may be prohibitory or mandatory 
in their nature, rights exist in a variety of guises. This may indeed have a far-reaching effect on the use of the term "right". As Gewirth notes,

'A complete rights-statement has the following structure: 'A has a right to $\mathrm{X}$ against $\mathrm{B}$ by virtue of Y.' There are five variables here: first, the subject of the right, that is, the person who is said to have the right (A); second, the nature of the right that is had, including its modality or stringency and the meaning of the statement that someone has the right; third, the object of the right, what it is a right to $(\mathrm{X})$; fourth, the respondent of the right, the person or persons against whom the subject has the right (B); fifth, the justifying reason or ground of the right, that by virtue of which the right is had (Y)' (Gewirth 1978, p. 65).

All rights must be held by a definitive right-holder. All rights must be correlative to, at least, one "duty-bearer". All rights must have as their object some active verb. All rights must comprise at least one of the Hohfeldian incidents.

\section{The Functional Scheme of Hohfeldian Rights}

It is possible to further develop Hohfeld's original scheme of jural relations by considering what each of these incidents applies to, that is, by considering its normative function. This is to be done by separating the incidents into two tiers, as briefly discussed above. In the first tier, we find Claim-rights and Privilege-rights and in the second tier, we find Power-rights and Immunity-rights. The first-tier rights govern objects (such as physical actions or states). This is to say that they are "rights" over certain objects. These are known as "rights over objects". In the second tier are those rights that concern the alteration, dissipation, or introduction of rights (or correlatives), or the prevention of alteration, dissipation, or introduction of rights. They are, therefore, "rights over rights" and might either allow the right-bearer to, in some way, change the position of another or change his own position or might protect that right-bearer from others changing his position.

The first-tier incidents are held over objects (where the bearer of the right is termed the subject); that is the relative thing governed by the right. Wenar notes, "On the first order, the paired privilege endows you with the discretion to move your body, or not to move your body, as you see fit. The claim on the first order affords you protection; it correlates to a duty in each other person not to touch your body." (Wenar 2005, p. 233) For instance: in the claim that $Y$ does not enter onto X's land, we find that the object that the right is held over is the land. Similarly, $X^{\prime}$ s claim that $Y$ not strike him is a claim-right over X's body. The same can be seen in privilege-rights, such as X's privilege of using his land or moving his body.

As for the second tier, we find Power-rights and Immunity-rights, the foundation being that these are incidents which are held over other incidents. The incident applies to some other incident whether held by the individual or by some other person. Wenar notes:

'On the second order are your rights regarding the alteration of these first-order rights. Here we see the paired power that gives you the discretionary authority to waive your claim against others touching your body: your right, that is, to authorize others to touch your body. Also on the second order is your protective immunity against other people waiving your claim not to be touched: your right, that is, against anyone else authorizing others to touch your body' (Wenar 2005, p. 233).

For instance: X's power to allow others to touch him, thereby altering his claim-right or Y's immunity from $X$ altering his claim-right that $X$ does not enter onto $Y^{\prime}$ s land.

The scheme can be further divided if we are to recognize a separation between those Hohfeldian incidents which are held "actively" and those which exist "passively". Some incidents can be enjoyed without the need to act upon them (the bearer needs not perform some act or behavior to enjoy them), whereas others require the exercise of the bearer to be useful. Active incidents, therefore, are the Power-right and the Privilege-right; notably, the power-right is in the second tier and the 
privilege-right in the first tier. Meanwhile, Immunity-rights and Claim-rights are passive incidents; again, the immunity-right is in the second tier and the claim-right in the first tier.

The effect is that each of the Hohfeldian incidents has a unique tier and "activity" combination, but also shares common features with other incidents. It also has a "contra"-right, which has the opposite combination of features. Thus, a Power-right is a second tier, active incident; a Privilege-right is a first tier, active incident; a Claim-right a first tier, passive incident; and an Immunity-right a second tier, passive incident. By further developing the original Hohfeldian scheme, we give ourselves a further analytical device for understanding the assertion "X has a right to $\phi$ ", beyond simply looking at the opposite and correlative.

In addition to this order of rights based on what they are held over and their function as exercised or enjoyed rights, Wenar also goes on to contend that each of the Hohfeldian incidents has one of six specific functions. ${ }^{10}$ These specific functions may be of exemption, discretion, authorization, protection, performance, or provision. Exercised rights hold one of the first three functions, whilst enjoyed rights hold one of the latter three functions. This is illustrated in Table 2.

Table 2. Basic Order and Function of Hohfeldian Incidents (Adapted from Wenar 2005).

\begin{tabular}{ccc}
\hline & $\begin{array}{c}\text { Active Rights } \\
\text { "X has a right to } \phi\end{array}$ & $\begin{array}{c}\text { Passive Rights } \\
\text { "X has a right that } Y(\text { not }) \phi "\end{array}$ \\
\hline $\begin{array}{c}\text { Second Tier } \\
\text { Rights over } \text { rights }\end{array}$ & POWERS & IMMUNITIES \\
First Tier & Piscretion or Authorisation & Clion \\
Rights over objects & PRIVILEGES & Cxemption or Discretion \\
\hline
\end{tabular}

It is now necessary to structure each of these functions regarding the Hohfeldian incidents. As illustrated in Table 2, a Claim-Right may hold the function of protecting the right-holder from harm, of providing something necessary to the right-holder, or it may require performance of some specified action. So, for instance, we have rights against others assaulting us, rights to education in childhood, or rights to be paid by our employers, respectively (Wenar 2005, p. 229). It is enjoyed in that it does not require the right-holder to do anything, in and of itself, to activate the right but, instead, compels the duty-bearer to perform or refrain from some specified action.

A Privilege-Right meanwhile is manifested by the assertion that " $X$ has a right to (not) $\phi$ ". It is then an exercised right. As noted in Table 2, it may hold a function of either discretion or exemption. Wenar claims that Privilege-Rights are held either singularly or in pairs. When Privilege-Rights are paired, they provide the right-holder with discretion as to how to act in a given situation or within given circumstances. In Hohfeldian terms, the holder of a paired Privilege-Right is under no duty to $\phi$, nor are they under a duty to $\phi$. I have, for example, a discretionary Privilege-Right as to whether or not I subscribe to a religious organisation. ${ }^{11}$ On the other hand, a singular Privilege-Right provides the right-holder exemption from some general duty. For instance, a driving license provides me with an exemption from the general duty not to operate a dangerous vehicle on the road. Similarly, a police officer may have an exemption from the general duty to injure you if you are resisting arrest. It appears that in Hohfeld's own discussion of Privilege-Rights, he had in mind the two-fold nature of these rights as creating either an exemption (Hohfeld 1964, pp. 38-40), or a discretion (Hohfeld 1964, p. 51; Hilton v Eckerley 1856, p. 74).

A Power-Right is also manifested by the assertion "X has a right to (not) $\phi$ ". However, unlike a Privilege-Right, which is found in the first tier and so operates over objects, a Power-Right operates

10 It is beyond the scope of this paper to consider the normative dimension of this claim in respect of the more common theories of rights (interest and will theories).

11 Notably, there are derogations from and qualifications to this. 
over other rights (Hohfeld 1964, p. 51). ${ }^{12}$ As Wenar notes, "We have not only privileges and claims, but rights to alter our privileges and claims, and rights that our privileges and claims not be altered." (Wenar 2005, p. 230) It is, therefore, a device for altering one's own or another's rights. As noted in Table 2, a Power-Right may hold the function of either authorisation or discretion. As with Privilege-Rights, Wenar considers that Power-Rights may be held singularly or in pairs, creating either a simple authorization or a discretion. For example, one may have a Power-Right to authorize the sale of their house when an offer is received (Hohfeld 1964, p. 55), or if there is more than one offer, they may have a discretionary Power-Right as to which offer is accepted. ${ }^{13}$

Finally, an Immunity-Right is manifested by the assertion " $X$ has a right that $Y$ not $\phi$ ". It denotes protection from harm or paternalism for the right-holder from the duty-bearer by preventing the latter from altering the normative situation of the former. For example, I have an Immunity-Right that you do not sell my house without my consent, thus protecting my interest in my property (Hohfeld 1964, pp. 60-61).

As I have already set out in this paper, it is imprecise to look at the Hohfeldian incidents in too much isolation. Frequently, discussions of assertions to "rights to $\phi$ " or indeterminate rights, such as the "right to free speech" or the "right to abortion", are used as tools to express more complex molecular rights wherein numerous incidents will combine to form the right to a given thing. This is also highlighted using various segments of the "right to property ownership" (Quigley 2007). In this way, when we consider complex rights these functions will also combine to afford the right-holder, for instance, discretion and protection, or exemption and provision. Whilst the terminology is different from Wenar's formulation, it appears that Hohfeld recognized the different functions that might be served by each of the incidents and the various ways in which they might operate.

\section{Paucital and Multital Incidents}

Having considered in some detail each of the Hohfeldian incidents and how their molecular composition can bond to create complex rights, it is now necessary to consider another of Hohfeld's classifications. For Hohfeld (1964, p. 100), it was necessary to move away from terming rights in personam and in rem due to the misuse and misleading use of those terms. Instead, he proposed to term rights either paucital or multital (Hohfeld 1964, pp. 67-73).

In Hohfeld's framework, a paucital right (or a right in personam) is either a unique right residing in a single person and availing against a single person (or group of persons), or it is one of a few similar, yet separate, rights availing respectively against a few determinate persons (Hohfeld 1964, p. 72). A paucital right is, therefore, a right which occurs in a limited circumstance between notably limited persons. It is, therefore, unlike the more oft-asserted rights-to property, our bodies, speech, and so forth - and instead exists in a realm, which by and large, will be through the operation of the creation of "right-duty" relationships between persons. For example, A might contract (for consideration) with $B$ that the latter clear his garden; or $X$ might agree with $Y$ that $X$ will not do $\phi$ for the next six months. In this first situation, $X$ has altered his claim in rem as specifically against $Y$ over his land (his claim being that $Y$ does not enter onto his land); through this alteration a new duty has been assumed by $\mathrm{Y}$ (to enter onto his land and clear it), but $\mathrm{Y}$ also now has a privilege (through exemption from the general duty) to enter onto the land. Equally, $X$ maintains his claim in rem more generally but has created a new claim in personam against $Y$ (and interestingly, dissipated a claim that he not enter). In the second situation, $\mathrm{X}$ has created in himself a negative duty-he will refrain from doing $\phi$ during that time period. This is highlighted in the apt example, "I have a legal duty to my employer to teach Thursday's 10 am class, but no duty to you, the reader, to teach that class" (Edmundson 2012, p. 75).

12 It may be termed a legal 'ability' — this is useful terminology as it helps to understand the scope of the incident.

13 It should be noted that the choice to sell one's house, to begin with, appears to be a combination of an authorization Power-Right to waive one's rights to ownership and an Immunity-Right from being compelled to waive one's rights to ownership. 
Assuming that the action indicated by $\phi$ does not overlap with any other person's Hohfeldian incident, the claim that $X$ does not do $\phi$ exists only in $Y$ and exists solely between those persons.

In contrast to this, a multital right (or right in rem) is one of a large class of fundamentally similar yet separate rights, both actual and potential, residing in a single person but availing respectively against persons constituting a large, indeterminate class of people (Hohfeld 1964, p. 72). These multital rights are therefore accurately recognized as being rights held against the world in general. It is more likely that those who are exempt from this more general duty are determinate. ${ }^{14}$ Privileges (and to a lesser extent Immunities) will be held multitally simply because they will be rendered ineffective if even only a single person holds a claim (Edmundson 2012, p. 75). They exist because of the absence of duty (not) to do $\phi$; it must, therefore, be held against the world. To put it another way, my privilege exists on the basis that no other person holds a claim that I do otherwise. Take the following examples. Suppose that $\mathrm{X}$ is a smoker who holds a privilege to smoke (where the law permits it) multitally, as against the world. Suppose, further, that $X$ promises $A$ that she will refrain from smoking. Now, $X^{\prime} s$ privilege remains against the world but she also owes a duty to $A$ that she abstains. The effect being that whilst $B$ would have no claim that $X$ abstain from smoking, $X$ is duty-bound to refrain at all times. $X^{\prime}$ 's privilege against the world still holds but its effectiveness has been diminished by the duty to $\mathrm{A}$.

Interpreted in this way the term 'in personam' is directly substitutable for the Hohfeldian term paucital and 'in rem' substitutable for multital. However, given the misuse of the Latin terms, in this paper, the Hohfeldian terms will be adopted for conceptual clarity. By considering the compass of the right (Austin 1885, p. 370), we are enabled to frame the scope of the assertions to rights that are made. Equally, we can reflect upon the meaningfulness of certain assertions based on the scope they must possess to operate effectively.

This aspect of the Hohfeldian framework remains vitally important in modern rights discourse for two principle reasons to which I will next turn. It is key to understanding the amplification of rights within a given community and it is central to the understanding of how individual assertions to rights function within these networks. It is to this 'Rights Network' which I now focus.

\section{The Rights Network}

In this section, I set out the basis for the rights network, an understanding of Hohfeldian logic across an entire community and the necessary amplification therein. It will be shown that the implementation of a rights-based system necessitates the exponential growth of connections between individuals within a given network. It will be established that this exponential growth is one of the key merits to the system.

To demonstrate this growth, we must begin by establishing a sequence of rights-connections within a group of persons wherein each member of the group holds a single in rem Claim-right against other members. There will thus be two rights-connections between any two individuals given the reciprocity of those Claim-rights which each member holds. A group of two persons in this system will, therefore, have two rights-connections. By increasing the group to three persons, we will find that there are now six rights-connections. A group of four persons will, therefore, have twelve right-connections, and so on. This exponential growth in right-connections can be expressed as ${ }^{15}$ :

$$
I_{n}=I_{n-1}+2 \mathrm{n}
$$

Beginning with a single individual and increasing by one member each time, we are provided with the following sequence:

$0,2,6,12,20,30,42,56,72,90,110,132,156,182,210, \ldots$

14 For instance, those persons who will be in a known alternate normative situation, such as police officers, judges, etc.

15 I am indebted to Dr Mustafa Al-Ani for his mathematical wherewithal in formulating this idea in these terms. 
This sequence can be represented as:

$$
I_{n}=\sum_{k=1}^{k=n} 2 k
$$

This demonstrates that in a standard classroom, holding fifteen members, the group would have 210 right-connections between them were they to each hold only one in rem Claim-right. Interestingly then, if we take the population of the UK as $65,000,000^{16}$, this would result in $4,225,000,000,000,000$ (4.225 quadrillion) right-connections held across the network.

What if each of the individuals held an in rem molecular right encompassing one of each of the Hohfeldian incidents? Now the sequence can be represented as:

$$
I_{n}=\sum_{k=1}^{k=n} 8 k
$$

The sequence then runs as:

$$
0,8,24,48,80,120,224,288,360,440,528,624,728,840,960, \ldots
$$

Here, our 15-person classroom comprises 960 right-connections. Whilst the UK network would comprise 16,902,600,000,000,000 (>16.9 quadrillion) right-connections.

Finally, if we take that the US Bill of Rights contains 24 Rights within the 10 amendments ${ }^{17}$, then across the $323,000,000$ members of the network ${ }^{18}$, there are $2,503,900,000,000,000,000$ (>2.5 quintillion) right-connections. ${ }^{19}$

This uniquely and aptly demonstrates the exponential amplification of rights within a network. This is still merely a snapshot of the Rights Network; the real network is far bigger, the connections unfathomably large (if they were not already) and diverse. Yet the rights analytic set out by Hohfeld allows the deconstruction and abstraction of these incidents that are unpacked across a vast scale network.

Rights are a unique legal mechanism in the network connections which they create; they interconnect us in a way that other legal rules do not. The institution of a legal rule affects our behaviors (or permitted behaviors) across an entire network but it exists only once. Rights, on the other hand, connect our behaviors to others what seems infinitely. They are further shaped and qualified by other corresponding rights (those in the second tier) of our own and of others, by the interconnected individuals' behaviors and by natural events; they are inherently qualified by numerous circumstances, which shape the contours of the rights we hold. Each abstract reference or assertion of an in rem "right" (in the UK) is an assertion that 4.2 quadrillion rights exist within that network. For each of these, there may be further corresponding rights—such as the power-right to amend it, the immunity-right from it being removed, the claim-right to compensation if it is infringed, the privilege-right(s) to use (or not) use it-an extra 4.2 quadrillion rights exist alongside it. Simultaneously, with each "right" that is created, there is a correlative obligation (as Hohfeld identified), and so a further 4.2 quadrillion obligations are established with each connection. Obligations that in some way limit the bearer's behavior. This is then a delicate balance on an unfathomably large scale. In both ways, then, the growth is exponential.

16 It is currently slightly higher at 65.64 million. Population total accessed from the World Bank (http:/ / data.worldbank.org/ indicator/SP.POP.TOTL?locations=GB).

17 http://www.ushistory.org/us/18a.asp. It should be recognized that there are almost certainly not 24 Hohfeldian rights contained within the Bill of Rights as some of those listed in the graphic will be molecular rights.

18 Rounded down from 323.1 million. Population total accessed from the World Bank (http:/ / data.worldbank.org/indicator/ SP.POP.TOTL?locations=US).

19 Here our sequence function is: $I_{n}=\sum_{k=1}^{k=n} 48 k$ 
By understanding rights as a network existing across a community, we are better enabled to consider the distribution of rights and duties therein. Whilst the networks outlined above are overly simplified, it demonstrates the propensity for the actual network to be set out. That is, we can picture and map the restraints of behaviour, positive freedoms, and levels of normative control provided by these Hohfeldian incidents. Analysis of the distribution of rights to individuals based on age, gender, race, occupation, educational status, task competence, and sexuality is achievable. As is the complexity of the ties between individuals, groups, and based on propinquity. All of which helps to provide a measure of reciprocity or mutuality across the network.

Individual assertions to rights are often problematic. As I have already outlined, they may be mistakenly defined and devoid of conceptual underpinning. Further to this, rights are often expressed in an absolutist manner. As demands to do as one pleases or to have others curtail their behaviors to the benefit of the individual claiming the right. Yet, few, if any, rights are absolute. Rights are necessarily qualified by the right-holder's own behaviors, by natural circumstance, and by the reciprocated rights of others. I will outline the conditionality and qualification of right-holding in more detail in the following section, for now, I will focus on how rights function as a network. In doing so, I will consider four issues: first, I will tackle the problem posed by an "overload of duties"; second, I will address the types of rights held within a network (i.e., human rights, legal rights, moral rights etc.); third, I will discuss the notions of mutuality and qualification; and, finally, I will examine the problem of "open" and "closed" duties.

\subsection{Overload of Duties}

The first issue to consider for the Rights Network is the proposed problem of an "overload of duties". Essentially, the idea is that to impose the number of duties necessitated by the Rights Network-seemingly unlimited and open-ended-would drastically limit or threaten our freedom. However, duties (that is, any Hohfeldian correlative) can be collapsed in the same way that the Hohfeldian incidents can be using the paucital and multital framework. In this instance, my 64,999,999 paucital duties not to strike others can be collapsed into a multital duty not to strike people. Any instances where my duty is amended in respect of another right-holder is to be treated, then as a single paucital (qualified) exemption from my general duty not to do otherwise. To put it another way, I know that I have a general multital duty not to enter onto land which is not my own without permission. If you give me permission to enter your land this does not affect my existing multital duty, but creates an exemption privilege to enter your land. Furthermore, many "duties" or Hohfeldian correlatives are simply the absence of a (claim-)right or power. These instances do not, in that sense, limit one's freedom, but rather denotes the interpersonal liberty afforded to us. Both Immunity-Rights and Privilege-Rights are emblematic of circumstances where the bearer of the Hohfeldian correlative (Disability and No-Claim, respectively) have no legal authority to do otherwise.

\section{2. "Types" of Rights}

A further challenged faced to the Rights Network is the demarcation between different "types" of rights. By this, I mean the perceived distinction between Human, Legal, and Moral rights. The problem here, as I see it, is in the varied use of terms, especially the phrase 'Human Rights'. 'Human Rights', or an assertion to a 'Human Right', is often used to imply some moral authority and, therefore, priority over other legal rights (Hohfeld 1964, p. xi). Yet, this is often done without evidence for such moral authority (Gewirth 1996) and without recognition that a human right in law must have the same conceptual makeup as any other legal right for it to have any deontological or normative meaning. That is, it must fit within the Hohfeldian framework. As such, any human right in law is simply a legal right. As noted, Hohfeld's framework solves no problems of justice or social policy for us, but it does allow us to see the problem at hand for what it is and direct our arguments of moral authority or justice or social policy accordingly. A claim seeking recognition of a human right over a, say, property right is simply a claim to restrike the balance between two competing rights. 


\subsection{Benefits and Burdens: Mutuality and Qualification}

In the models put forward in imagining the rights network, they have necessarily been perfectly mutualist. Each individual holds the same portfolio of rights against each and every other individual and, correlatively, owes duties to each and every other individual. Each individual is both the subject and respondent of the rights. Yet in actual rights networks, this is neither what occurs, nor is it necessarily desirable. The balance of rights across a network is struck by the importance of the nature of the right to the individual. Mutualism is not as straightforward as "if A must do some $\mathrm{X}$ to $\mathrm{B}$ ... [then] B must do some X for A" (Gewirth 1996, p. 75). The value of X will depend, in some cases, on where A (or B, or C, etc.) is situated within a community based on biological, psychological, social, and/or functional features. By example, a network may restrict certain rights in children (in comparison to adults), or it may provide further rights to those performing certain roles for the performance of that role (for example, police officers or judges), or it may provide rights that can only sensibly allocated to one of the sexes (for example, the right to abortion), or individuals may by agreement establish new or amended right connections between them (for example, by contract or by trust). A true conception of the rights network must be capable of perceiving this balance.

Nevertheless, such an imbalance might indicate inequality. Rights may be withheld from certain members for reasons that relate not to their humanity or their agreement. The rights network, if fully mapped, allows for these inequalities to be understood and traced across a given network. For instance, by mapping individual nodes and the extent of their rights-connections in a sociogram.

The absence of perfect mutualism in a rights network, however, is not a cause of the supposed adversarial nature of rights. Rights-talk, it is often supposed, is used as a means of excluding others and claiming extensions of one's power. Yet, as Gewirth notes, "It is ... a mistake to hold that all rights-talk is exclusively concerned with fulfilment of one's own selfish interests." (Gewirth 1996, p. 90) Except in conceptions of ideal societies, conflict is a part of human social life. Individuals can and do act in ways that may negatively affect others. Rights respond to this potentiality and "can serve to moderate as well as to express adversarial relations among persons." (Gewirth 1996, p. 90) The effect is that,

'when mutual rights are effectively recognized, and especially when this recognition is stabilized in effective institutions, the adversarial stance can and often does give way to an atmosphere of the kind of mutual respect and civility which is an important part of the value of community' (Gewirth 1996, p. 90).

That is, it is in the mapping of a full rights network, and in understanding the variety of connections drawn across it, that we might identify where intolerable imbalances are found and new rights introduced to rebalance the power within that network.

Against this position, Glendon (1991, p. 14) has argued,

'Our rights talk, in its absoluteness promotes unrealistic expectations, heightens social conflict, and inhibits dialogue that might lead toward consensus, accommodation, or at least the discovery of common ground. In its silence concerning responsibilities, it seems to condone acceptance of the benefits of living in a democratic social welfare state, without accepting the corresponding personal and civic obligations ... In its insularity, it shuts out potentially important aids to the process of self-correcting learning. All of these traits promote mere assertion over reason-giving' (Glendon 1991, p. 14).

The ease of use of the language of rights, it is said, leads to confrontation rather than negotiation between parties. Yet, this appears to be a problem with the misuse of the language of rights rather than the language of rights itself, or at least a misunderstanding of the Hohfeldian framework outlined here (Wenar 2008, p. 265). As Gewirth (1996, p. 91) counters, "the desiderated removal of adversarial relationships and the fostering of community may well depend on the implementation rather than the rejection of rights." It is in the understanding of the Hohfeldian scheme of rights as extending connections across a given network that we can truly appreciate the balance of rights, as entitlements, 
and duties, as responsibilities. The Rights Network in this way accounts for one of the biggest lines of criticism levied towards rights-talk is its over individualization. That claim is essentially that much rights-talk is based on assertions from one group or individual over others, specifically the prioritization of the interests of one over the interests of others. It ought to be clear by this point that rights do not occur in isolation. The assertion that " $X$ has right that $Y \phi^{\prime}$ " exists alongside other rights relating to that Claim-Right. Alongside, $X$ might have Privilege-Rights, Power-Rights and Immunity-Rights that combine to form the complex structure of a molecular right. Yet, equally and importantly with many rights, $Y$ may have identical or similar rights against $X$, as might $Z$. Take the right to bodily integrity by way of example: $X^{\prime}$ s Claim-Right that $Y$ not strike him is reciprocated by Y's Claim-Right that $X$ not strike her. In this mutuality comes an important derogation from each of their Privilege-Rights over their bodies, namely the Privilege-Right (the absence of a Claim-Right of another) to move one's body as one wishes. This Privilege-Right, then, is qualified by the Claim-Right. Its contours are shaped by the rights of another. A similar scenario is clearly seen with regard to real property. It is my Privilege-Right to use my property as I choose; that is, my neighbor has no Claim-Right that I use my property in any particular way. The neighbor does, however, have a Claim-Right to the quiet enjoyment of their own property, and as such, my Privilege-Right is curtailed, as is my neighbor's Privilege-Right (Hohfeld 1964, p. 28, 96). Few, if any, rights are absolute, and it is the mutualism and qualification of rights that we seek to distribute the benefits and burdens of rights-holding.

In a similar manner, rights are often conditional. Suppose my right to bodily integrity is constituted only by the Claim-Right that you do not strike me and the Privilege-Right to move my body as I so wish, a molecular right which is reciprocated in you. If I use my body to strike you, not only do I go beyond the qualification of my Privilege-Right but I also extinguish my Claim-Right that you do not strike me because it is held conditionally. This is because the Claim-Right is subject to the condition of your own Privilege-Right of self-defense (Hohfeld 1964, p. 94). Similarly, the property rights I hold in my house are conditional upon me paying my mortgage. If I were to default on my payments, the mortgagor would have the Privilege-Right to sell the house, thereby extinguishing the Immunity-Right held in this regard. Halpin considers the Claim-Right of a dock owner (D) against another (C) mooring their boats at his dock (Halpin 2007). In the event of peril caused by a violent storm that Claim-Right is extinguished and $\mathrm{C}$ would hold a Privilege-Right to dock. Here, the Claim-Right is conditional upon the risk of more serious consequences to another.

Rights are held reciprocally, conditionally, and subject to qualification. Much rights-talk is expressed under the guise of absolutism and abstraction. An assertion "It is my right to do $\phi$ " does not consider the vast array of rights connected to, reciprocated by others, nor those conditions or qualifications for that right to be held. Hohfeld's conceptual task to explain and set out each of the incidents may, at first reading, be seen as an impediment to a universal account of the social conventions of right-holding. Yet it is only when we understand the nature and conception of these individual incidents and how they form complex structures, within the individual right-holder and across the community (Gewirth 1996), that we can properly understand the effects that corresponding obligations may exist within that complex structure. Few would argue that the rights attained from goods, such as bodily integrity, autonomy, property ownership, education, health, free speech, reputation, privacy, and even life, do not come with responsibilities attached.

\subsection{The Duty Problem: "Open" and "Closed" Obligations}

Hohfeld's scheme has been subjected to considerable criticism specifically on the correlativity of duties (or, more broadly, "obligations" ${ }^{20}$ ). The problem, it is said, arises from Hohfeld's failure to devote much time to the concept of duty (Freeman 2008, p. 398) and, in failing to do so, omitted to

20 The term "duty" is used predominantly in this section to save on confusion between the usage by other authors and myself. 
recognize that there is no mutual correlativity of claims and duties (Edmundson 2012, p. 80). That is, the assertion that all claims are correlative to duties but failing to recognize that not all duties correlate to claims (Lyons 1970, pp. 45-55; Gewirth 1978, p. 66). As such, non-correlative duties have no place within the Hohfeldian scheme; his thesis is related to rights since open duties do not give rise to rights they are not within his scheme (Freeman 2008, p. 398). An example of a non-correlative (or open) duty that given by Raz is, "[A] government may have a duty to try to improve the standard of living of all its inhabitants of the country even though no single inhabitant has a right that the government shall try to improve his standard of living." (Raz 1986, p. 182) Prohibitions and obligations exist within the law that do not have a recognizable, correlative right-bearer; without an explanation for these occurrences, the term "duty" appears vague and ill-defined.

In seeking to resolve this oversight, it is submitted that a conceptual explanation exists by reference to "open" and "closed" duties. ${ }^{21}$ It is worth, however, noting that it is, in my opinion, more of a semantic oversight on the part of Hohfeld in failing to define each plausible obligation; his scheme focuses on legal relations between individuals, and duties without a correlative right have no place in such a scheme. The argument then is that "open" duties are those obligations held in law with no definable right-bearer. Therefore, open duties are those which MacCormick describes as imposed to protect the rights of others (MacCormick 1982). Examples include the duty of charity (Edmundson 2012, p. 80), or to wear a seatbelt, or to pay taxes, or the example given by Raz (1986). Put simply, they are those obligations placed upon us to (not) do certain actions or to (not) be in certain states (Johnson v Phillips 1976) (Simmonds 2008, p. 278). Meanwhile, "closed" duties are those obligations that do have a definable right-bearer; these are those that fit easily within the Hohfeldian scheme. Simply, a closed duty is a duty in the sense that Hohfeld meant it, namely a duty that is correlative to a right in some other person (Hohfeld 1964, p. 38). Although both are termed duties and represent obligations, similar to other Hohfeldian correlatives, it is thus only the latter that will apply within our scheme of jural relations and, therefore, that are relevant to the current thesis.

An example of the above qualification can be found in the law relating to breach of statutory duties. So, when a statute provides an obligation or prohibition which is remedied in a specified manner then that obligation is owed generally and not against any definable individual. ${ }^{22}$ However, exceptions exist in relation to this. First, an Act may specifically provide for a remedy, and hence the right of action, ergo that duty is closed, as an individual would then be able to assert a right to be remedied (if they have standing). ${ }^{23}$ Second, the court may interpret the Act, on its "true construction", as imposing the obligation for the benefit (or protection) of a particular class of individuals. ${ }^{24}$ Third, the statute creates a public right (which can be enjoyed by each and every individual) and a particular member suffers "particular, direct, and substantial". ${ }^{25}$ This is, essentially, the legal means of determining whether a statutory obligation is an "open" or a "closed" duty.

21 The terminology is less important here than the concept itself; terms such as "broad" and "narrow"; "defined" and "undefined"; and "determinable" and "undeterminable" duties. Edmundson (2012, p. 81) terms them as "perfect" and "imperfect" duties. Even "Hohfeldian" and "non-Hohfeldian" obligations would be apt.

22 Doe d. Murray v. Bridges. 1831. 1 B. \& Ad. 847, 859, per Lord Tenterden CJ quoted in Lonrho Ltd v. Shell Petroleum Co (No. 2). 1982. AC 173.

23 See, for example, s150 Financial Services and Markets Act 2000.

24 Lonrho Ltd v. Shell Petroleum Co (No. 2). 1982. AC 173, at 185, per Lord Diplock. See Groves v. Lord Wimborne. 1898. 2 QB 402; cf: Atkinson v. Newcastle Waterworks Co. 1877. 2 ExD 441.

25 Benjamin v Storr 1874, 401 per Brett J. See also: Lonrho Ltd v. Shell Petroleum Co (No. 2). 1982. AC 173, at 186, per Lord Diplock: ' . . . if B has first to be shown that the statute, having regard to its scope and language, does fall within that class of statutes which creates a legal right to be enjoyed by all of Her Majesty's subjects who wish to avail themselves of it. A mere prohibition upon members of the public generally from doing what it would otherwise be lawful for them to do, is not enough.' See also, Boyce v. Paddington Borough Council. 1903. 1 Ch. 109. 


\section{Concluding Remarks}

In this paper, I set out to return to Hohfeld's own work and consider developing these ideas using an analysis of Hohfeld's formulations within an expanding network wherein these rights form connections between individuals. In doing so, I set out to demonstrate how fundamental it is as a tool for our considerations of the value and nature of rights. Without it, I claim, rights-talk is ultimately debased and meaningless. It provides us with an analytic method for understanding, deconstructing, and more fully expressing our assertions to rights, and therein to determine the balance of freedom across our communities. The nature of rights is complex, each of the incidents implies a separate correlative and the merging of our expressions as to which Hohfeldian incident leads to confusion. For example, if I assert that I have a right to kill myself, what I mean is that I am free-you or anyone else has no-claim that I not kill myself-yet simultaneously others may feel that they are under a duty to stop me if they see me doing so, even if they believe I am doing it authentically. But this duty is in response to either: (a) my claim-right that I am offered protection from my own attempts to end my life (assuming, of course, that I do not have or have not exercised a power-right to waive this claim), or (b) this duty is an open, public duty to protect others who we perceive to be in need of assistance-and this may be a legal or moral duty which we find ourselves under. The oversimplification of the rights discourse leads to fundamental misunderstandings of the meaning behind the language of rights.

The approach provided thus far concerns the conceptual framework of rights deriving from the Hohfeldian rights analytic. It has used Hohfeld's scheme as a starting point from which to develop, and noted that the scheme can be expanded from mere correlatives and opposites to encompass a first and second tier (concerning rights over objects and rights over right respectively) and the passive or active nature of the rights in question.

It has been noted that these incidents may exist in people, subject to certain qualifications and conditions that shape the contours of the incident whilst leaving its basic form in place. Finally, I have considered the existence of incidents held paucitally and mulititally, and discovered that it is only the external characteristics of the incident that is amended, leaving the internal arrangement of the incident separate, distinct, and individual.

Whether we term "rights" as Legal, Moral, Equitable or Human, it is vital that the conceptual framework set out in this paper is adhered to. The conceptual framework says nothing about the reason or source for the right but requires that things which we term as "rights" follows this logical structure. This requires being clear in our expression of rights, that they adhere to the expression of either enjoyed, exercised, or molecular rights. The popularity of rights grew when grasped by the exploited and injured as a means of claiming protection and empowerment. With this came a loosening in the language adopted, and with that rights-talk became debased. There is, at present, a move away from the language of rights as a result. Rights, it is said, imply individualism and conflict. This paper has attempted to demonstrate the value of rights-talk and rights-based approaches when they are understood and expressed in line with the most concise and thorough conceptual framework of rights available to us.

To understand how this conceptual framework of individual incidents of rights can help us to understand the vast matrix of rights-based relations across a given society, I have sought to imagine these relations as forming a rights network. In doing so, I set out the inherent exponential amplification of rights within an expanding network. By understanding rights, specifically Hohfeldian rights, existing as connections between individuals throughout a given community, we are able to perceive the complex manner in which our societal relations are formed and framed by both benefits and burdens, rights and responsibilities. Whilst the version of the rights network outlined in the paper was a basic one, focusing principally on the extension and exemplification of simple multital rights across of network of similarly placed individuals, the approach allows for an appreciation of the complexity of a given rights network. 
Yet, rights cannot do as much as is asked of them. They cannot cover every legal relation or reason for action. If there is a continued insistence to express all demands in the language of rights, then the approach will be futile (Cornell 2015, pp. 141-43). It must be challenged, otherwise Hohfeld's painstaking analysis will be in vain. Most importantly, it is vital to consider the correlative of any assertion of right posed to us; is the claim that there is a Duty or is it the absence of Claim-Right? When an assertion cannot be expressed within the Hohfeldian scheme or deconstructed as a combination of separate elements, it is not a right. It must be expressible as either: (1) assert the right holder's ability to (not) perform some act- "X has a right to (not) $\phi$ ", (2) the duty bearer's requirement to (not) perform some act- "X has a right that $Y(n o t) \phi$ ", or (3) it is an assertion that one has a right in or to a thing- "X has a right to $A$ ". If it cannot, then any demand we are seeking to make must be expressed in other terms. But this does not detract from the cause. The "right" adds no value to the assertion in and of itself. Perhaps, some 100 years after he originally constructed his rights analytic, this is where the value is to be found in Hohfeld's work for the modern legal theorist.

Funding: This research received no external funding.

Acknowledgments: Many thanks to Lisa Webley, Emma McClean, and Joe Tanega for their comments on early drafts of this work. To Mustafa Al-Ani for his help formulating the equations in Section 6 and to the anonymous reviews for their feedback.

Conflicts of Interest: The author declares no conflict of interest.

\section{References}

Austin, John. 1885. Lectures on Jurisprudence or the Philosophy of Positive Law, 5th ed. London: John Murray. Brady, James. 1972. Law, Language and Logic: The Legal Philosophy of Wesley Newcomb Hohfeld. Transactions of the Charles S Peirce Society 8: 246-63.

Campbell, Tom. 2006. Rights: A Critical Introduction. Abington: Routledge.

Corbin, Arthur. 1921. Jural Relations and Their Classification. Yale Law Journal 30: 226-38. [CrossRef]

Cornell, Nicolas. 2015. Wrongs, Rights, and Third Parties. Philosophy and Public Affairs 43: 109-43. [CrossRef]

Edmundson, William. 2012. An Introduction to Rights. Cambridge: Cambridge University Press.

Freeman, Michael DA. 2008. Lloyd's Introduction to Jurisprudence, 8th ed. London: Sweet and Maxwell.

Gewirth, Alan. 1978. Reason and Morality. Chicago: Chicago University Press.

Gewirth, Alan. 1996. The Community of Rights. Chicago: Chicago University Press.

Glendon, Mary Ann. 1991. Rights Talk: The Impoverishment of Political Discourse. New York: Free Press.

Griffin, James. 2008. On Human Rights. Oxford: Oxford University Press.

Halpin, Andrew. 2007. Rights, Duties, Liabilities, and Hohfeld. Legal Theory 13: 23-39. [CrossRef]

Hohfeld, Wesley. 1913a. Fundamental Legal Conceptions as Applied in Judicial Reasoning. Yale Law Journal 23: 16. [CrossRef]

Hohfeld, Wesley. 1913b. The Relations between Equity and Law. Michigan Law Review 11: 537. [CrossRef]

Hohfeld, Wesley. 1917a. Fundamental Legal Conceptions as Applied in Judicial Reasoning. Yale Law Journal 26: 710. [CrossRef]

Hohfeld, Wesley. 1917b. The Conflict of Equity and Law. Yale Law Journal 26: 767.

Hohfeld, Wesley. 1964. Fundamental Legal Conceptions as Applied in Judicial Reasoning. London: Yale University Press.

Lyons, David. 1970. The Correlativity of Rights and Duties. Nous 4: 45-55. [CrossRef]

MacCormick, Neil. 1982. Legal Right and Social Democracy. Wotton-under-Edge: Claredon Press.

Quigley, Muireen. 2007. Property Rights in the Human Body: Applying Honore. Journal of Medical Ethics 33: 631-34. [CrossRef] [PubMed]

Raz, Joseph. 1986. The Morality of Freedom. Oxford: Oxford University Press.

Simmonds, Nigel. 2008. Central Issues in Jurisprudence. Oxford: Oxford University Press.

Stone, Julius. 1964. Legal System and Lawyers' Reasoning. Stanford: Stanford University Press.

Veerman, Phillip. 1992. The Rights of the Child and the Changing Image of Childhood. Leiden: Martinus Nijhoff Publishers. Wacks, Raymond. 2009. Understanding Jurisprudence, 2nd ed. Oxford: Oxford University Press.

Wellman, Carl. 1975. Upholding Legal Rights. Ethics 86: 49-60. [CrossRef]

Wenar, Leif. 2005. The Nature of Rights. Philosophy and Public Affairs 33: 223-52. [CrossRef] 
Wenar, Leif. 2008. The Analysis of Rights. In The Legacy of H.L.A. Hart: Legal, Political, and Moral Philosophy. Edited by Matthew H. Kramer, Claire Grant, Ben Colburn and Antony Hatzistavrou. Oxford: Oxford University Press. Wenar, Leif. 2011. Rights. The Stanford Encyclopedia of Philosophy. Edited by Edward N. Zalta. Available online: http:/ / plato.stanford.edu/archives/fall2011/entries/rights/ (accessed on 1 May 2018).

White, Alan. 1985. Rights. Oxford: Oxford University Press.

(C) 2018 by the author. Licensee MDPI, Basel, Switzerland. This article is an open access article distributed under the terms and conditions of the Creative Commons Attribution (CC BY) license (http:/ / creativecommons.org/licenses/by/4.0/). 